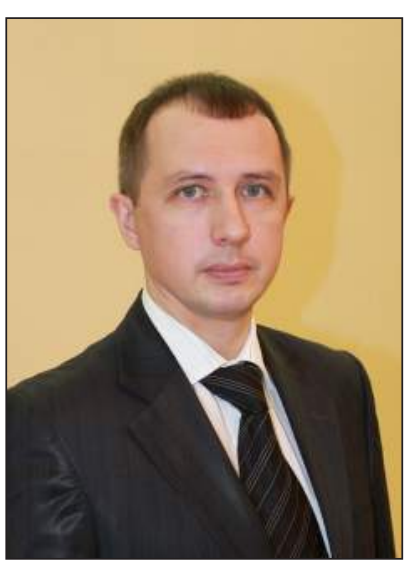

\author{
Лук'янов Дмитро Васильович, \\ кандидат юридичних наук, доцент, \\ в.о. головного вченого секретаря \\ Начіональна академія правових наук України, \\ Україна, м. Харків \\ e-mail:d_lukyanov@list.ru \\ ORCID 0000-0003-2540-5488
}

\title{
YAK 340.5
}

\section{РЕАІГІЙНІ ПРАВОВІ СИСТЕМИ: ВИКАИКИ СУЧАСНОСТІ}

У статті розглянуто вплив світових глобалізаційних процесів на розвиток релігійних правових систем. Автор наполягає, що прочеси глобалізацї мають будуватися на повазі до культурної, релігійної та правової багатоманітності, забезпечувати ї̈ збереження від примусової «вестернізащї». Звернуто увагу на значні відмінності впливу глобалізащї на зближення правових систем західного права (романо-германського та англо-американського) та їх впливу на релігійні правові системи мусульманського, індуського та іудейського права, які внаслідок таких особливостей, як божественний характер, підвищена стабільність, несистематизованість норм, спещифічні джерела права, майже не піддаються впливу інших систем та відповідним змінам.

Ключові слова: глобалізація, релігійні правові системи, релігійне право.

Луквянов Д. В., кандидат юридических наук, доцент, и.о. главного ученого секретаря, Национальная академия правовых наук Украины, Украина, г. Харьков.

e-mail : d_lukyanov@list.ru ; ORCID 0000-0003-2540-5488

\section{Религиозные правовые системы: вызовы современности}

В статье проанализовано влияние мировых глобализационных процессов на развитие религиозных правовых систем. Автор настаивает, что процессы глобализации должны строиться на уважении к культурному, религиозному и правовому многообразию, обеспечивать ее от принудительной «вестернизации». Обращается внимание на значительные различия влияния глобализации на сближение правовых систем западного права (романо-германского и англо-американского) и их влияния на религиозные правовые системы мусульманского, индусского и иудейского права, которые в результате таких особенностей, как божественный характер, повышенная стабильность, несистематизированность норм, специфические источники права, почти не подвергаются воздействию других систем и соответствующим изменениям.

Ключевые слова: глобализация, религиозные правовые системы, религиозное право.

Постановка проблеми. Світ на порозі ХХІ ст. вступив у якісно новий етап свого розвитку, який характеризується глибинними змінами всіх аспектів людського буття. У науці ці процеси описуються як «глобалізація», «форму- 
вання постіндустріального світу», «інформаційного суспільства», «перехід на ноосферний шлях розвитку», i, відповідно, висловлюються суперечливі оцінки, пропонуються різні вектори подальшого розвитку світової цивілізації [1, с. 90]. Все більше науковців визнають, що глобалізація стає провідною тенденцією світового розвитку. Її навіть називають «кліше нашого часу» [2, с. 1]. Ця тенденція з часом охоплює все більше країн та все більші групи людства зазнають впливу. Цей суспільний процес відбувається в діяльності та взаємовідносинах індивідів, різних соціальних груп і прошарків, націй і цивілізацій. Водночас питання впливу цих процесів на розвиток правових систем світу, зокрема на релігійні системи, є недостатньо дослідженими у світовій науці та майже зовсім не досліджуваним у вітчизняній юридичній науці.

Актуальність теми. Водночас розвиток та взаємодія правових систем світу є важливим фактором ефективного та безпечного розвитку всього людства. Сучасний світ змінюється все більш швидкими темпами. Так, за різними оцінками Європа лише у 2015 р. прийме близько одного мільйона біженців [3], більшість з яких є носіями нетипової для Свропи мови, релігії, культури, права. Досвід показує, що тісний зв’язок економіки, політики, культури, права та релігії різних цивілізацій призводить інколи до несподіваних та негативних наслідків. Достатньо згадати низку конфліктів навколо карикатур на Пророка Мухамеда та мусульман взагалі. Тому дослідження питання впливу цих процесів на релігійні правові системи, дія яких поширюється на третину всього людства, є надзвичайно актуальним.

Аналіз останніх досліджень $\boldsymbol{i}$ публікащій. Спочатку новий дискурс щодо міжнародних змін будувався навколо понять «світове», «міжнародне», «інтернаціоналізація». Термін «глобальне» було включено до нього лише в середині 1960-х pp., коли В. Мур (W. Moore) увів у обіг термін «глобальна соціологія» [4, с. 477], а M. Маклюєн (M. McLuhan) - термін «глобальне село» [5, с. 76]. Власне, дискурс глобалізації в суспільних науках виникає в середині 1980-х pp., коли це поняття став розробляти і популяризувати Р. Робертсон (R. Robertson) [6; 7]. У цей період більшість досліджень теорії змін було зосереджено на новому генеральному напрямку - розробці теорій глобалізації. 31990 р. виходить програмний збірник статей «Глобальна культура» [8], в якому опубліковано роботи провідних теоретиків цієї проблеми. 3 цього часу одна за одною з’являються фундаментальні монографії про глобалізацію Л. Склера (L. Sklair) [9], Р. Робертсона (R. Robertson) [10], А. Аппадураї (A. Appadurai) [11] та інших дослідників. Зміст концептуального повороту, який відбувся в суспільних науках, чітко сформульовано у вступі М. Фезерстоуна (M. Featherstone) і С. Лаша (S. Lash), до збірника статей «Глобальні сучасності» (Global Modernities): дискурс глобалізації виник як «спадкоємець дебатів про сучасність (modernity) і постсучасність (postmodernity) у розумінні соціокультурних змін» [12, с. 1].

На початку XXI ст. формується новий напрямок досліджень з проблем глобалізації - глобалізація в сфері права, i, зокрема, вплив глобалізації на різні правові сім’і сучасності. Це, серед іншого, роботи: С. Зіфкака (S. Zifcak) «Гло- 
балізація і верховенство права (Виклики глобалізації) («Globalisation and the Rule of Law (Challenges of Globalisation)», 2005), Ш. Райт (Sh. Wright) «Міжнародні права людини, деколонізація, глобалізація: становлення людства» («International Human Rights, Decolonisation, Globalisation: Becoming Human», 2005), Д. Б. Голдмана (D. B. Goldman) «Глобалізація і західна правова традиція: паттерни права і влади (право в контексті)» («Globalisation and the Western Legal Tradition: Recurring Patterns of Law and Authority (Law in Context)», 2008), В. Твайнінга (W. Twining) «Загальна юриспруденція - розуміння права в глобальній перспективі» («General Jurisprudence - Understanding Law from a Global Perspective», 2009), р. Домінго (R. Domingo) «Нове глобальне право» («The New Global Law», 2011), C. Сассена (S. Sassen) «Територія, влада, права: від середньовіччя до глобальних об'єднань» («Teritory, Authority, Rights: From Medieval to Global Assemblages», 2008), А. Слотера (A. Slaughter) «Новий світовий порядок» («A New World Order», 2005), П. С. Бермана (P. S. Berman) «Глобальний юридичний плюралізм: теорія права крізь кордони» («Global Legal Pluralism: A Jurisprudence of Law Beyond Borders», 2012), С. Річардса (S. Richards) «Глобалізація як фактор загальної юриспруденції» («Globalization as a Factor in General Jurisprudence», 2012) тощо.

Meтою статmi є аналіз впливу різноманітних глобалізаційних процесів на розвиток та взаємодію правових систем світу, передусім релігійних правових систем, та окреслення подальших тенденцій їх розвитку.

Виклад основного матеріалу. 3 90-х рр. ХХ ст. глобалізація стала визначальним фактором світового розвитку і міжнародних відносин. Відбувається руйнація єдності національних держав і національних суспільств, утворюються нові конкурентні співвідношення, конфлікти та непорозуміння між національно-державними єдностями і транснаціональними системними ідентичностями (в тому числі й на конфесійній основі). Світ переживає перехід від національної історії до транснаціональної, відчуває факт появи транснаціонального життєвого простору, універсалізації способу життя, символів культури, формування транснаціональних форм поведінки. Глобалізація руйнує самоідентифікацію гомогенного, закритого, замкнутого на себе національно-державного простору, руйнує кордони різних сфер життя, у т. ч. й релігійного.

Глобалізаційні процеси в XXI ст. тією чи іншою мірою стосуються як окремих індивідів, так і цілих народів, держав, цивілізацій. Глобальні трансформації призводять до якісних змін у системі соціокультурних взаємовідносин, актуалізуючи широке коло проблем, пов'язаних із формуванням нової світової культури. Так, С. Хантінгтон (S. Huntinfton) наголошує на «зіткненні цивілізацій» [13, с. 112], теорії Ф. Фукуями (F. Fukuyama) погрожують «кінцем історії» [14, с. 57], Е. Тоффлер (А. Toffler) розробляє концепцію «кліп-культури» [15, с. 213] тощо. Діапазон поглядів на явище глобалізації широкий: від заперечення згаданого процесу і твердження, що глобалізація є перебільшенням і як ідеологічна конструкція, і як аналітичне поняття (В. Райгрок (W. Ruygrok) та ін.), до констатації гіперглобалістами (К. Омае 
(K. Ohmae) та ін.) всеохоплюючого характеру глобалізації, що, на їх думку, призведе до зникнення національних держав.

Однією з найбільш дискусійних проблем є визначення сутності глобалізації. У деяких зарубіжних і вітчизняних дослідженнях акцент зроблено на економічних аспектах глобалізації, формуванні фактично єдиного світового ринку товарів і послуг (К. Волтз (К. Waltz), Дж. Стігліц (J. Stiglitz), Д. Хелд (D. Held)), або на формуванні єдиного інформаційного простору (М. Делягін (M. Delyagin), М. Кастельс (M. Castells)), на розвитку єдиних поведінкових стандартів, єдиного способу життя, системи цінностей (Г. Ділігенський (G. Diligenskiy), С. Кара-Муза (S. Kara-Murza), T. Сакайя (T. Sakaya), Ю. Габермас (J. Habermas)) [16, с. 92].

Досить поширеним тривалий час у літературі залишався вузький погляд на глобалізацію - вона зводилася суто до економічних процесів. Так, зокрема, дискусії про глобалізацію, що набули популярності починаючи з кінця ХХ ст., відбувалися в контексті економічного дискурсу щодо ринкової лібералізації, масштабу і глобального охоплення транснаціональних корпорацій тощо. У економічній науці і сьогодні глобалізацію розглядають здебільшого як прояв інтернаціоналізації економіки, розвитку єдиної системи світових зв'язків, зміну і послаблення функцій національної держави, активізацію діяльності транснаціональних недержавних утворень, у тому числі таких, як етнічні діаспори, релігійні рухи тощо [16, с. 21]. Юридичне обговорення часто слідувало в фарватері цих економічних і геополітичних тенденцій [17, с. 42]. Одним із визначальних моментів у вирішенні цієї дискусії стала резолюція Генеральної Асамблеї ООН 55/102 2000 р., в якій, зокрема, було сказано, що глобалізація є не тільки економічним процесом, вона також має соціальні, політичні, екологічні, культурні і правові аспекти.

Усе це призводить до постановки нових завдань у межах порівняльно-правових досліджень, адже «порівняльне правознавство сьогодні здобуває статус науки майбутнього як засіб розуміння різного права і різних культур у світі, що глобалізується» [18, с. 1]. Перед ним стоїть завдання із вироблення життєздатних стратегій щодо розвитку «плюралістично-чутливої, глобально-свідомої теорії права». У той же час, на адресу юридичної науки й академічної спільноти лунають звинувачення в перебільшеній євроцентричності. Зокрема, B. Твайнінг (W. Twining) вказує, що, на відміну від такої науки, як геологія, яка грунтується на універсальних фізичних законах, право є культурно залежним. Це базове застереження покладає величезні зобов'язання на теоретиків права і компаративістів щодо надання інформації «читачеві постмодерну», нинішній генерації студентів, щодо того, як розуміти право і його найрізноманітніші прояви у по-справжньому глобальному контексті [19, с. 30].

В основі всіх теорій глобалізації, і ця характеристика яскраво знаходить прояв в дослідженнях в сфері права, лежить дихотомічна типологія соціальної організації: локальна versus глобальна, яка також знаходить прояв в дискусії щодо універсальності відповідних правових цінностей, незалежно від куль- 
турної приналежності того чи іншого суспільства. Як вказує з цього приводу C. I. Максимов (S. Maksimov), процеси глобалізації сучасного світу, в якому співіснують і взаємодіють різноманітні культури, змушують звернути увагу на вимогу знаходження оптимального співвідношення універсально-цивілізаційних і культурно-специфічних моментів у праві, оскільки правова система має, з одного боку, засновуватися на універсальних правових цінностях і принципах, а з іншого - орієнтуватися на певну культурно-правову традицію [20, с. 57-58]. Одним із ключових питань для юристів сьогодні стає питання про те, якою мірою глобалізація може означати гармонізацію або навіть уніфікацію права в усьому світі. У цьому «інтелектуальному лабіринті юриспруденції» (B. Моррісон (W. Morrison)) ми заперечуємо припущення, відповідно до якого в певний момент майбутнього вже не буде ані індуського, ані мусульманського, ані іудейського права. Ці внутрішньо складні правові системи постійно змінюються й будуть піддаватися змінам в майбутньому, однак є нереалістичним припускати, що вони коли-небудь поступляться своїм місцем певному космополітичному глобальному праву.

Традиційно серед основних тенденцій розвитку права в умовах глобалізації виділяють такі:

1) універсалізація права, під якою необхідно розуміти відображення в національних правових системах загальновизнаних норм і принципів міжнародного права. Загальною закономірністю, яка позначає процес глобалізації, є подолання більш автономних політичних, економічних, соціальних і релігійних общин. Вони стають елементом єдиного загального простору, який має певні універсальні правила взаємодії. Адже на перший план виходить гармонізація та пошук спільних правил поведінки;

2) регіоналізація права, що становить собою процес правового регулювання міжнародних відносин, суб'єктами яких є територіальні (регіональні) економічні і політичні союзи, міжнародні організації тощо (наприклад, Європейський Союз, Рада Європи, Організація зі співробітництва і безпеки в Свропі та ін.), а також окремі регіони держав, які можуть виступати учасником міжнародних відносин;

3) зміна національного права під впливом норм і принципів міжнародного права; в умовах глобалізації норми міжнародного права на основі конституційно (законодавчо) закріпленої моделі співвідношення нормативних правових актів мають більшу юридичну силу щодо національного законодавства;

4) взаємовплив правових систем сучасності, який призводить до нівелювання особливостей правових систем, має наслідком іх зближення, взаємне проникнення [21, с. 8-9].

У цьому контексті постає питання про вплив глобалізації на релігійні правові системи, яке фактично змушує замислитись над явищем глобалізації в більш масштабному контексті - у світлі їі впливу на цивілізаційний розвиток суспільств. 
Як ми вже вказували, концепція глобалізації первісно формувалася як економічна теорія під впливом процесів все більш зростаючих взаємозв'язків і взаємної залежності серед різних країн світу завдяки все більшій економічній відкритості і трансграничному обміну капіталами, товарами, послугами, ідеями, людьми. Ці процеси традиційно пов'язуються із західною цивілізацією. Доволі частими в літературі є твердження, які вказують на те, що процес глобалізації є двигуном самоствердження та ідеологічної гегемонії західної цивілізації, поширення західних цивілізаційних цінностей і способу життя. Усі ці процеси впливають і на право, причому в такий спосіб, який призводить до ситуації, «коли не має сенсу говорити про незалежно існуючі правові культури». За цим сценарієм розвитку правові сім'ї, засновані на інших правових традиціях, приречені на поступове зникнення.

Однак існує й інша точка зору, прибічники якої вказують на недоццінку з боку «універсалістів» спротиву універсалізації з боку суспільств, які не відносять себе до західної цивілізації [22, с. 41]. Дискусія про вплив глобалізації на сучасний світ неминуче ставить питання і про універсальність нашого розуміння права. У буденній правосвідомості глобалізація часто асоціюється із гармонізацією правил поведінки, створенням єдиного правового простору. Це, у свою чергу, зумовлює формування припущення про те, що за умов глобалізації виникає менше конфліктів, оскільки відносини у суспільстві регулюються за однаковими правовими моделями, заснованими на універсальних правових цінностях. Противники такої точки зору висловлюють скепсис щодо реалістичності уніфікації існуючого багатоманіття. Мрії про таку універсалізацію, які плекає глобалізація, заходять занадто далеко у своєму некритичному сприйнятті переваг всезагальної стандартизації. $€$ відірваними від реальності очікування, що весь світ буде керуватися єдиною системою правил, використовувати одну мову і мати одну культуру.

У центр уваги сьогодні, особливо в контексті дослідження релігійних правових систем, потрапляє питання щодо того, чи має і чи може феномен глобалізації грунтуватися на ідеї загальносвітової стандартизації (уніфікації)? Або ж, навпаки, глобалізація не заперечує необмежену різноманітність, підкреслює плюралізм правових систем, цінностей, що лежать в їх основі, і плюралістичні ефекти глобалізаційних процесів є більш реалістичними? Ці питання змушують також під іншим кутом зору подивитись на спроби теоретиків права виробити загальну концепцію розуміння права, надати універсальну характеристику права, яка була б актуальною для будь-якої правової традиції, для будь-якого суспільства. Звернення до релігійних правових систем засвідчує значні суперечності у розумінні права. Існуючий сценарій світового розвитку вказує на зростаючу різноманітність локальних рішень, незважаючи на триваючий пошук глобальної уніфікації. На наше переконання, наполягання на антиплюралістичному баченні світу, необхідності уніфікованого його сприйняття $є$ надзвичайно небезпечним для глобального миру і благополуччя. «Західні юридичні претензії на універсальність закриті незахідною перспективою» 
(Ч. Macai (Ch. Masaji)) [23]. Певною мірою, коли ми говоримо про суперечності у баченні права між світськими і релігійними правовими сім'ями, фактично йдеться про «конфлікт цивілізацій», раніше описаний дослідниками. Такий підхід видається хибним, оскільки він сфокусований на занадто вузькому баченні «християнсько-ісламського» контексту, яке залишає поза своєю увагою багато інших глобалізаційних претензій у світі. Сприйняття цього протистояння суто як двостороннього («західного» і «мусульманського») є занадто спрощеним і небезпечним, так само як і занадто нечітким та обмеженим.

Незалежного від справжньої природи існуючого конфлікту й від конкретного бачення «глобальної уніфікації», мирне співіснування в глобально взаємопов'язаному світі неможливе без забезпечення простору, в якому визнається допустимість різних бачень i, відповідно, повага до них, що є, за словами Ліотарда, «прагненням до справедливості і прагненням до невідомого» [24, с. 67].

Водночас дослідники висловлюють багато скепсису щодо такої перспективи. Той самий Ж.-Ф. Ліотард (J.-F. Lyotard) підкреслює розбіжності й зазначає, що «консенсус - це горизонт, який неможливо досягнути» [25, с. 61]. Е. Мелісаріс (E. Melissaris) доходить висновку, що вивчення правового має бути спрямовано на відкриття альтернативних уявлень про світ, справедливість, а також про різні моделі вирішення практичних проблем шляхом примирення конфліктуючих інтересів і задоволення потреби в субстантивній справедливості [26, с. 76]. Питання про право і справедливість в результаті стає одним із тих питань, що визначає весь наш спосіб життя, яким є наше самосприйняття й бачення свого місця в світі. Існуючі теоретичні підходи, не тільки серед правників, частіше за все тяжіють до європоцентричності, а тому зазнають поразки в спробі зобразити глобальну картину світу, охопити плюралістично-чуттєву перспективу. Правова доктрина, як видається, серйозно відстає від реальності, для якої залишається характерною дуже значна багатоманітність. Глобальна міграція, давня і нинішня, численні обмінні процеси між державами, економіками, суспільствами, правовими системами, в різних масштабах і за допомогою різних методів забезпечують крізь час транснаціональний, по суті плюралістичний, багатоетнічний, мультикультурний характер правової реальності. Автори юридичних досліджень, що задають тон сучасної юридичної науки, продовжують поводити себе так, ніби глобалізація просто означає уніфікацію, опираючись доказам з усього світу, що глобальна гармонія можлива лише шляхом якомога більшої толерантності до різноманітності, а не за допомогою примусової уніфікації.

За зізнанням В. Твайнінга (W. Twining), глобалізація дійсно робить світ більш взаємозалежним, але це не означає, що ми невблаганно рухаємося до єдиного загальносвітового управління, і не свідчить про зникнення національних держав як найбільш важливих суб’єктів [27]. Скоріше, має йтися про все більшу плюралізацію, аніж про глобальну гомогенізацію.

Отже, глобалізація має своїм результатом скоріше змішаність, а не уніфікованість, розгалужений, мультицентричний світ як «гіперплюралістичне 
транснаціональне суспільство». I це є аргументом для того, щоб виробити механізми, які дозволяють почути всі голоси, присутні в суспільстві, під час триваючих у ньому дискусій, забезпечити повагу багатоманітності. Ставлячи питання про те, чи існує основна (ключова) правова традиція в світі, яка б могла витіснити все інше право у решті світу, П. Гленн (P. Glenn) відповідає: «Відповідь полягає в тому, що немає жодного універсального ядра. Це є гарною новиною для стійкості головних, комплексних правових традицій світу» [28, с. 331]. А отже, глобалізація не може сподіватися на існування поза глибокою повагою до багатоманітності й плюралізму в світі. Відповідно, правові системи світу мають вивчатися в дусі поваги до багатоманітності як невід'ємного елемента глобального правового порядку.

Висновки. Сучасні процеси глобалізації затягують у власну орбіту все ширше коло різноманітних суспільних відносин. Взаємовідносини між правовими системами в XXI ст., на наш погляд, стають одними з найбільш важливих аспектів цього процесу. Водночас взаємодія правових систем має суттєві відмінності від взаємодії, наприклад, економічних систем різних країн. Якщо в економічних відносинах спостерігається фактичне домінування західних фінансово-економічних інститутів та уніфікація відповідних норм, то намагання застосувати такий підхід до права призводить до спротиву західним стандартам та поширенню значних цивілізаційних конфліктів у різних частинах світу. Процеси глобалізації мають будуватися на повазі до культурної, релігійної та правової багатоманітності, забезпечувати її збереження від примусової «вестернізації». Необхідно підкреслити також значні відмінності впливу глобалізації на зближення правових систем західного права (романо-германського та англо-американського) та їх впливу на релігійні правові системи мусульманського, індуського та іудейського права. Останні внаслідок таких особливостей, як божественний характер, підвищена стабільність, несистематизованість норм, специфічні джерела права, майже не піддаються впливу інших систем та відповідним змінам. Важливим питанням, яке потребує подальшого дослідження, є зворотній вплив, що здійснюється релігійним правом на сучасні правові секуляризовані системи.

\section{Список літератури:}

1. Мельник В. В. Глобалізація в культурній сфері: теоретико-методологічний аналіз / В. В. Мельник // Гуманітарний вісник ЗДІА. - 2010. - Вип. 43. - С. 90-97.

2. Held D., McGrew A. Globalization / Anti-Globalization: Beyond the Great Divide / D. Held, A. McGrew. - Polity, 2007. - 304 p.

3. В 2015 году ЕС примет 1 млн запросов на убежище по прогнозу ОЭСР [Электронный pecypc]. - Режим доступа : http://www.interfax.ru/world/468489.

4. Moore W. Global Sociology: The World as a Singular System / W. Moore // American Journal of Sociology. - 1966. - № 5. - P. 475-482.

5. McLuhan M. War and Peace in the Global Village / M. McLuhan, Q. Fiore. - New York, Gingko Pr Inc., 2001. - 192 p.

6. Robertson R. Modernization, Globalization and the Problem of Culture in the World-Systems Theory / R. Robertson, F. Lechner // Theory, Culture \& Society. - 1985. - № 3. - P. 103-118. 
7. Robertson R. Globalization Theory and Civilization Analysis // Comparative Civilizations Review. - 1987, Vol. 17. - P. 129-138.

8. Global Culture: Nationalism, Globalization and Modernity / Ed. by Mike Featherstone. London : Sage Publications, 1990. - 411 p.

9. Sklair L. Sociology of the Global System / L. Sklair. - The Johns Hopkins University Press, 1995. - $352 \mathrm{p}$.

10. Robertson R. Globalization: Social Theory and Global Culture. London: SAGE Publications Ltd, 1992. - 224 p.

11. Appadurai A. Modernity at Large: Cultural Dimensions of Globalization / A. Appadurai. Minneapolis University of Minnesota Press, 1996. - 248 p.

12. Featherstone M. Globalization, Modernity and the Spatialization of Social Theory: An Introduction / M. Featherstone, S. Lash // Global Modernities. Ed. by M. Featherstone, S. Lash, R. Robertson. - London, 1995. - P. 1-25.

13. Хантингтон С. Столкновение цивилизаций / С. Хантингтон. - Москва : ООО «Издательство АСТ», 2003. - 603 с.

14. Фукуяма Ф. Конец истории и последний человек / Ф. Фукуяма ; пер.с англ. М. Б. Левина. - Москва : ООО «Издательство АСТ», 2007. - 588 с.

15. Тоффлер Э. Третья волна / Э. Тоффлер ; пер. с англ.- Москва : ООО «Издательство $\mathrm{ACT} \gg, 2004 .-781 \mathrm{c}$.

16. Тодыка О. Ю. Народовластие в условиях глобализации: монография / О. Ю. Тодыка ; под ред. А. В. Петришина, д-ра юрид. наук, проф., акад. АПрН Украины. - Харьков : Право, 2005. - 336 c.

17. Mohr R. Local Court Reforms and 'Global' Law / R. Mohr // Utrecht Law Review. - 2007. Volume 3. - Issue 1 (June). - P. 41-59.

18. Örücü E. The Enigma of Comparative Law Variations on a Theme for the Twenty-first Century / Esin Örücü // Springer-Science+Business Media, B.Y., 2004. - 242 p. $296 \mathrm{p}$.

19. Twining W. Globalisation and legal theory / W. Twining // London : Butterworths, 2000.--

20. Максимов С. И. Концепция правовой реальности / С. И. Максимов // Неклассическая философия права: вопросы и ответы. - Харьков : Б. в., 2013. - С. 57-58.

21. Глазатова Т. С. Современные тенденции развития права в условиях глобализации : дис. ... канд. юрид. наук : 12.00 .01 теория и история права и государства; история учений о праве и государстве / Т. С. Глазатова. - Москва : РАНХиГС при Президенте РФ, 2015. - 206 с.

22. Friedmann, W. Legal theory. London: Steven \& Sons. 1994 Дэвид Нелкен. Сравнительная социология права // Общество и право: исследовательские перспективы : [сб. ст.] / ред.-сост. А. Кондаков. - СПб. : Центр независимых социологических исследований, 2015. - XII с. - 384 с.

23. Chiba, Masaji. 1984. 'Cultural universality and particularity of jurisprudence'. In: Marasinghe, M. Lakshman and William E. Conklin (eds.) Essays in third world perspectives in jurisprudence. Singapore:Malayan Law Journal. - P. 302-326.

24. Lyotard, Jean-Francëois. 1984. The postmodern condition: A report on knowledge. Manchester : Manchester University Press. - P. 67.

25. Lyotard, Jean-Francëois. 1984. The postmodern condition: A report on knowledge. Manchester: Manchester University Press. - P. 61.

26. Melissaris, Emmanuel. 2004. 'The more the merrier? A new take on legal pluralism'. Vol. 13 No. 1. Social and Legal Studies. - P. 57-79.

27. Twining, William. 2000. Globalisation and legal theory. London: Butterworths.

28. Glenn H. P. Legal traditions of the world: Sustainable diversity in law / H. P. Glenn // Oxford : Oxford University Press, 2010. - 418 p.

Lukianov D. V., Candidate of Legal Sciences, Associate Professor, Acting Chief Scientific Secretary, National Academy of Legal Science of Ukraine, Ukraine, Kharkiv.

e-mail: d_lukyanov@list.ru ; ORCID 0000-0003-2540-5488 


\section{Religious legal systems: challenges of the modernity}

The influence of world globalization processes on the development of the religious legal systems has been analyzed in the paper.

Globalization processes in the XXI century are regarding individuals, nations, and civilizations. Global transformations lead to qualitative changes in the socio-cultural relations and actualize a wide range of issues which are related to the formation of a new world culture.

Modern globalization takes diverse range of public relations in its own orbit. The relationship between the legal systems in the twentieth century is some of the most important aspects of this process. However, the interaction of legal systems has significant differences from the interaction of economies of different countries. There are actual economic relations domination of Western financial and economic institutions and standardization of relevant rules. But the attempts to apply this approach to law lead to resistance to Western standards and the spread of major civilizational conflicts in different parts of the world. Globalization should be based on respect for cultural, religious and legal diversity. It has to ensure preservation of forced "Westernisation". Significant differences in the impact of globalization on the convergence of legal systems of Western law (Romano-Germanic and Anglo-American) and their impact on religious legal systems of Muslim, Hindu and Jewish law must be emphasized. The religious legal systems are not exposed to other systems and the related changes. This is due to such features as the divine nature, increased stability, specific sources of law etc.

An important issue that requires further study is the reverse influence which religious law exercises to secularized modern legal system.

Надійшла до редколегіï 25.08.2015 p. 